DOI: https://doi.org/10.32838/2523-4803/69-5-22

УДК 336.77

\title{
Юдіна C.B.
}

доктор економічних наук, професор,

завідувач кафедри фінансів та обліку,

Дніпровський державний технічний університет

\section{Синельна А.І., Назарчук Л.М.}

магістри,

Дніпровський державний технічний університет

\section{Yudina Svetlana, Sinelna Alona, Nazarchuk Lesya}

Dniprovsk State Technical University

\section{ОСОБЛИВОСТІ КРЕДИТУВАННЯ НАСЕЛЕННЯ В УКРАЇНІ}

У статті досліджено закономірності та особливості кредитування домогосподарств в Украӥні. Відзначено, щзо в сучасних умовах в Украйні зросла й роль кредиту у формуванні фінансових ресурсів вітчизняних домогосподарств. Визначено чинники, щяо впливають на обсяги кредитів: сезонність, вік позичальників, стать позичальників, приналежність до сфери діяльності та ін. Дано визначення закредитованості населення. Під надмірно закредитованими позичальниками запропоновано розуміти й тих, хто затримує платежі. Визначено основні чинники закредитованості населення 6 Украӥні: стан загальноекономічного розвитку; показники рівня життя населення; особисті чинники; фінансова грамотність та фінансова дисиипліна населення; чинники розвитку сфери кредитних послуг; інші. Зроблено висновки про необхідність розвитку кредитування домогосподарств в Україні, тому щзо воно позитивно позначається як на добробуті домогосподарств, результатах діяльності фінансово-кредитного сектору, так і на економіці Украӥни у цілому.

Ключові слова: кредитування домогосподарств, споживчі кредити, іпотечні кредити, позичальники, закредитованность населення, чинники закредитованості. 
Постановка проблеми. Кредитування населення $€$ одним із найпоширеніших видів банківських операцій у розвинутих країнах світу і одним зі стимулювальних чинників розвитку економік цих країн. Воночас кредитні ресурси стали впливати на добробут домогосподарств.

Але, на жаль, Україна $є$ одним із лідерів негативного рейтингу ефективності банківської системи за показником NPL. Причиною цього $€$ неприродньо високий рівень проблемних кредитів, який гальмує як банківський сектор, так і економічний розвиток.

Перехід банківської системи на міжнародні стандарти визначення проблемних кредитів дав змогу реально оцінити місце України у світовому рейтингу ефективності. Відповідно до проведених досліджень, на липень 2017 р. в Україні зафіксовано показник NPL у $58 \%$ - це найвищий рівень неповернення позикових коштів у світі. У 2010 р. в Афганістані був зафіксований рівень NPL 50\%, у Нігерії - 38\%. Погіршує ситуацію те, що з усіх проблемних кредитів понад $80 \%$ - це кредити, прострочення яких становить більше трьох місяців. Переважна частина проблем припадає на корпоративний сектор, саме тут зосереджені найбільші ресурси.

Портфель споживчого кредитування сьогодні $\epsilon$ одним із найбільш неактивних, за показником кредитування населення ми знаходимося на заключних позиціях, згідно зі статистикою, у співвідношенні до ВВП кредитування фізосіб становить приблизно 3,6\% [1].

Якщо говорити про причини такої ситуації, то можна виділити головні, а саме: проблеми $з$ економічною кризою, висока вартість кредитів, низька платоспроможність населення тощо.

Аналіз останніх досліджень і публікацій. Опосередковано питання кредитування населення досліджували з позиції запозичення досвіду. Але детального опису системи споживчого та іпотечного кредитування населення немає. Споживче кредитування з різних позицій досліджували: В. Василенко, І. Брітченко, Н. Меджибовська, А. Уляновський, Д. Гриньков, В. Мамутов [2] та ін. В їхніх працях досліджуються зміст і форми проведення споживчого кредитування, визначаються напрями його розвитку в Україні, проте системно не розглядалася і не вивчалася проблема закредитованості домогосподарств, не розглядалися чинники, що впливають на обсяги їхніх позикових ресурсів. Саме ці питання залишаються недостатньо вивченими і вимагають подальших досліджень.

Формулювання цілей статті. Метою статті $\epsilon$ дослідження закономірностей та особливостей кредитування населення в Україні та подальший розвиток підходів до визначення та оцінки закредитованості населення.
Виклад основного матеріалу. Як зазначив голова Національного банку України Я. Смолий, відновлення кредитування - це одна 3 пріоритетних цілей Національного банку на 2017-2018 pр. Я. Смолій зазначив, що 3 початку 2017 р. обсяг гривневих кредитів бізнесу зріс на $8,7 \%$, а кредитування населення в національній валюті - на $38,3 \%$.

Також голова НБУ вважає, що для повномасштабного відновлення кредитування необхідне забезпечення законодавчого захисту прав кредиторів, а також вирішення проблеми токсичних активів через прийняття відповідних законодавчих актів [3].

Ринкові відносини зумовили зміни в структурі джерел фінансових ресурсів для формування особистого бюджету вітчизняних домогосподарств. У сучасних умовах в Україні зросла й роль кредиту у формуванні фінансових ресурсів вітчизняних домогосподарств (табл. 1).

Як відомо, основними ознаками відносин, що становлять сутність кредиту є такі: учасники кредитних відносин мають бути економічно самостійними (функціонувати на основі самодостатності та самоокупності, нести економічну відповідальність за своїми зобов'язаннями); кредитні відносини є добровільними та рівноправним; кредитні відносини не змінюють власника цінностей; кредитні відносини $є$ вартісними, оскільки виникають у зв'язку з рухом вартості; нееквівалентність кредитних відносин значно посилюється через механізм платності їх реалізації, за яким позичальник повертає власникові більшу масу вартості, ніж одержував; кредитні відносини на мікроекономічному рівні є перервними, а на макроекономічному рівні вони підтримуються безперервно, забезпечуючи безперервний рух вартості у процесі суспільного відтворення; безперервність та платність кредитних відносин зумовлюють здатність забезпечувати зростання вартості, тобто ії капіталізацію.

У своїй перерозподільній функції кредит, який характеризується високою мобільністю, активно впливає на всі процеси суспільного відтворення. Насамперед, кредит відіграє значну роль в організації грошових розрахунків - готівкових і безготівкових. Він також допомагає суб'єктам господарювання збільшувати обсяги виробництва, забезпечувати безперебійність кругообігу основного й оборотного капіталу та уникати кризових явищ.

Особливо значна роль кредиту в задоволенні тимчасової потреби домогосподарств в коштах. Дедалі більшого значення набуває кредит у забезпеченні населення якісним житлом, побутовою технікою, створенні можливостей для отримання освіти та задоволення інших соціальних потреб. Сьогодні в Україні домогос-

Таблиця 1

Кредити домогосподарств у динаміці за 2005-2016 рр., млрд грн [3]

\begin{tabular}{|l|c|c|c|c|c|c|c|c|c|}
\hline Показник & 2008 & 2009 & 2010 & 2011 & 2012 & 2013 & 2014 & 2015 & 2016 \\
\hline Кредити & 280,5 & 241,2 & 209,5 & 201,2 & 187,6 & 193,5 & 211,2 & 174,9 & 163,3 \\
\hline
\end{tabular}


подарства використовують як грошову, так і товарну форму кредиту.

Але поки потенціал кредиту для підвищення якості життя вітчизняними домогосподарствами використовується вкрай недостатньо.

Безумовно, з розвитком ринкових відносин в Україні роль кредиту у суспільстві підвищуватиметься.

Сьогодні для домогосподарств найпопулярнішими є беззаставні кредити. Як правило, це кредитні картки, споживчі кредити, кредити на персональні цілі, іпотечні кредити. Деякі банки активно кредитують придбання авто.

На обсяги кредитування домогосподарств сильно впливає сезонність. Наприклад, улітку люди беруть кредит більше на ремонт або відпочинок, а восени - на розвиток бізнесу, освіту, весілля. Взимку активно купують техніку як новорічні подарунки.

За статистикою $70 \%$ від загального числа позичальників - це люди від 30 до 45 років. Це може бути пов'язано 3 тим, що кредитори вважають людей у цьому віці більш серйозними і заможними, щоб сплатити борг. Як правило, саме після 30 років люди мають стабільний заробіток і цінне майно.

Найчастіше кредит надають жінкам, причому заміжнім, бо жінки мають більшу довіру банків, аніж чоловіки, i, як правило, дотримуються платіжної дисципліни.

За родом діяльності кредити переважно видаються працівникам торгівлі, сільського господарства, сфери послуг і освіти.

Споживче кредитування активно розвиваеться в нашій країні. Так, 30-50\% усіх купівель у торговельних мережах здійснюють у кредит, лідирує серед них побутова та аудіо- і відеотехніка. Найбільш розповсюджена сума купівель у кредит - 300-400 дол. США. Близько $80 \%$ усього ринку споживчого кредитування сконцентровано у великих торговельних мережах «Фокстрот», «Ельдорадо» та ін. [4, с. 146].

Водночас експертні оцінки показують, що 20-30\% кредитів у нашій країні платяться із запізненням. Навіть високі штрафи не стимулюють позичальників до дисципліни. Це характеризує українців не як найзаможніших і сумлінних платників [5].

3 метою сприяння споживчому кредитуванню був прийнятий Закон України «Про споживче кредитування», який набрав чинності з 10.06.2017 [6].

Кредитування споживачів у зарубіжних країнах побудоване на жорстких законодавчих принципах. Так, усі фінансові та банківські операції щодо кредитів у Свропі базуються на законодавчих нормах та відповідають положенням загальнообов'язкових європейських директив. За недотримання хоча б одного з положень незалежно від того, з чиєго боку (кредитодавця чи споживача), передбачена відповідальність. Усі кредитні інститути Європейського Союзу незалежно від форми власності мають відповідати нормам безпеки, що передбачає обов'язкове страхування кредитних операцій. Таким чином, у разі виявлення зловживань із боку фінансової установи або недотримання нею умов договору споживач у судовому порядку може вирішити питання на свою користь [7].

Наприклад, у Німеччині порушення вимог із боку фінансової установи тягне за собою санкції і компенсації споживачам, які прописані в законі про кредитування, що є основним у процесі оцінки відповідності дій кредитних інститутів.

Кожна фінансова установа будь-якої європейської держави є безпечною для державної економіки та викликає довіру у позичальників, а споживач, своєю чергою, захищений на законодавчому рівні. Наслідком чітко виписаних правових норм у сфері споживчого кредитуванні $є$ високий ступінь довіри до такого кредитування.

В Україні, незважаючи на недовіру населення до банківської системи, все ж таки популярність споживчих кредитів не зникає. Кожна людина може $з$ легкістю отримати споживчий кредит у будь-якому банку у зручний спосіб та з мінімальною затратою часу. Для декого кредитування є єдиним виходом зі скрутної ситуації, а велика кількість банків може надати позику на умовах, що задовольняють споживачів.

Прийняття Закону «Про споживчі кредити» $є$ важливим елементом у механізмі вдосконалення фінансово-кредитної системи в Україні. 3 огляду на внесені зміни, на нашу думку, банківське кредитування домогосподарств повинно пожвавитися. Проте не тільки кредитування є показником здорової банківської системи, а й депозитні вклади населення.

Поступово відбувається вдосконалення механізмів функціонування вітчизняної фінансової системи, хоча швидкість реалізації реформ у цій сфері, як і в багатьох інших, мала би бути значно більшою. Часто ініціативи держави щодо захисту прав споживачів, у даному разі фінансових послуг, або ж є запізнілими, або взагалі відсутні. На нашу думку, така ситуація є результатом прихованого або й відкритого лобізму різноманітних фінансових установ, у тому числі банків, у середовищі наших законотворців.

Коротко проаналізуємо досвід деяких європейських країн щодо кредитування населення. Сьогодні для українців може бути цікавий досвід Польщі у цій сфері.Так, Польща займає шосте місце в Свропейському Союзі за кількістю взятих населенням кредитів. Послуги кредитування широко поширені. Гроші у кредит можна отримати навіть через Інтернет у віртуальних платіжних системах. Банки в Польщі лояльно ставляться до кредитоотримувачів. Навіть без високої заробітної плати можна отримати кредит для покупки або будівництва власного житла. Ставки по кредитах при цьому досить низькі, приблизно 5\% річних.

Згідно з опублікованою загальноєвропейською статистикою, 90\% працездатного польського населення живе в кредит, а в середньому кожен житель Польщі винен банкам трохи більше 800 євро. Це один із найвищих показників в Європейському Союзі. Більше всіх у кредити в СС затягнуті жителі Кіпру та Греції, а менше - Литва, Латвія і Бельгія [8]. 
У країнах Єврозони вартість житлових кредитів для позичальника $€$ настільки низькою $(3,5-3,75 \%)$, що порівняно з рівнем інфляції (3,0-3,5\%) для споживача іпотечний кредит є фактично безкоштовним.

Наприклад, у Німеченні параметри іпотечного кредитування такі: базова вартість - від 15\% до $30 \%$, термін кредитування - від 20 до 30 років, відсоткова ставка за кредит - від 7\% до $10 \%$. Водночас у Німеччині надаються пільгові кредити для сімей з обмеженими доходами. Пільгові кредити першої необхідності можуть отримати особи з низькими доходами, вони $\epsilon$ безпроцентними і супроводжуються виплатою субсидій. Пільгові кредити другої необхідності надаються особам із середнім доходом.

Тобто у розвинутих країнах держава встановлює загальні правила, що забезпечують ефективність взаємодії всіх учасників процесу житлового кредитування. Прямо або опосередковано держава використовуе бюджетні засоби для залучення додаткових інвестицій у житлову сферу. Державне регулювання іпотечного кредитування передбачає надання державних субсидій, гарантій, страхування. Безперечно, що така державна підтримка робить іпотечний кредит доступнішим для широкого кола осіб.

Уважаємо, що вищевкладене доцільно використовувати й у вітчизняній практиці кредитування домогосподарств [9].

Починаючи з 2014 р. фінансовий стан вітчизняних домогосподарств суттєво погіршився, проте боргове навантаження на сектор домогосподарств залишається незначним. На нашу думку, основна причина такої ситуації полягає у масовому відтоку працездатного населення на заробітки за межі України. Інші причини зумовлені, як уже зазначалося, зниженням реальних доходів домогосподарств та погіршенням їхньої кредитоспроможності, невизначеністю фінансового стану в майбутньому тощо.

Виходячи 3 даних, наведених у табл. 1, показники боргового навантаження домогосподарств знизилися, тобто споживче кредитування має значний потенціал.

Цьому буде сприяти й поступове зростання доходів населення. Так, частка заробітної плати у ВВП була у 2016 р. значно нижча, ніж у докризовий період, $-36,8 \%$ проти $50 \%$ у 2013 р. Виходячи зі статистичних даних, цей показник у II кварталі 2018 р. становив 45,5\% [10]. Реальний наявний дохід населення у 2016 р. вперше за три роки зріс на $0,3 \%$ (у післякризовому 2010 р. - на 17,1\%).

Підвищення зарплат дає змогу погашати старі банківські кредити: відношення боргу домогосподарств до наявних річних доходів у 2016 р. скоротилося 3 $14 \%$ до $11 \%$ [11].

Основні чинники закредитованості населення в Україні: стан загальноекономічного розвитку; показники рівня життя населення; особисті чинники; фінансова грамотність та фінансова дисципліна населення; чинники розвитку сфери кредитних послуг; інші.
На нашу думку, в Україні недостатньо досліджено рівні надмірної заборгованості населення. По-перше, це пояснюється недостатньою статистичною базою для дослідження, а по-друге, населення та фахівці тільки почали стикатися з наслідками цієї проблеми як для конкретної особи, так і держави у цілому.

Під надмірно закредитованими позичальниками мають на увазі тих, хто затримує платежі. Однією 3 ознак збільшення надмірної заборгованості населення України $\epsilon$ те, що частка респондентів, які затримали платежі за поточними кредитами більше ніж на 30 днів, вища, ніж частка тих, у кого були прострочені платежі по вже погашених кредитах.

Проте такий підхід до визначення надмірної закредитованості є спрощеним, адже для визначення рівня заборгованості використовуються показники заборгованості за кредитами та комунальними платежами. При цьому не враховується низка інших негативних життєвих обставин, які можуть бути ознакою можливої надмірної заборгованості.

До чинників, які потенційно можуть спровокувати надмірну заборгованість, можна віднести: відмову у наданні позики, неофіційні кредити, необхідність скорочувати витрати на їжу й пошуку додаткової роботи у зв'язку з виплатою кредиту, несприятливі обставини в родині, відсутність контролю фінансового становища, проблеми в сім'ї через борги, відсутність поліпшення у фінансовому становищі та ін.

Цікавим є дослідження, що здійснюється GfK Ukraine. Згідно з регулярним дослідженням цієї організації ринку банківських послуг, визначено, що серед фізичних осіб у 2016 р. взяли позику в банках 8,8\% дорослого населення України (віком від 16 років) [12].

GfK Ukraine у своєму дослідженні рівень заборгованості оцінювала 3 використанням двох підходів до сегментації позичальників. Обидва вони дали змогу визначити глибину заборгованості серед населення, що мало досвід позик у фінансовій установі, а також для вимірювання ймовірності виникнення надмірної заборгованості.

Перший підхід - це сегментація занепокоєння, який дає змогу виявляти диференціацію позичальників відповідно до сили фінансового тиску, якого зазнають позичальники.

Аналіз позичальників за допомогою сегментації занепокоєння показав, що лише близько $9 \%$ українських позичальників не відзначають негативного впливу кредиту на їхній спосіб життя і фінансову поведінку. 16\% мають заборгованості за кредитом або комунальними платежами. Майже $36 \%$ респондентів були змушені скоротити витрати на продукти харчування і знайти додаткову роботу для погашення боргів. Решта позичальників характеризуються меншою чи більшою схильністю до надмірної заборгованості залежно від обставин. Це диференціювання й відображено сегментацією.

Другий підхід - це сегментація ризику, який демонструє кластеризацію позичальників, ураховуючи не 
тільки вищезазначені проблеми, а й їхні фінансові можливості.

За результатами дослідження виявилося, що 74\% всіх позичальників (це ті, хто зазнає найбільшого впливу від закредитованості) мають високу частку витрат у доході, яка перевищує 75\% (при цьому низькою часткою витрат у доході вважається показник до $50 \%$; середньою - від 50\% до 75\%; високою - понад $75 \%$ ). Частка тих, хто можуть дозволити собі виплати по кредитах та здатні контролювати свої зобов'язання, становить лише $1,2 \%$ опитаних.

Виходячи з вищенаведеного, зрозуміло, чому банки збільшують іпотечне кредитування дуже повільно. Сьогодні середній дохід покупців житла в кредит становить 23,6 тис грн, тоді як середня заробітна плата на 01.08.2018 становила 8,977 тис грн. Тобто значна частина вітчизняних домогосподарств не може скористатися такою фінансовою послугою [11].

Хоча, як зазначалося вище, існує й проблема закредитованості й узагалі непогашення боргів. Більшість банків основною перешкодою для відновлення кредитування називає дефіцит платоспроможних позичальників 3 офіційно підтвердженими доходами. До речі, за даними НБУ, у 2017 р. загальна частка проблемних кредитів становила 57\%. За інформацією Нацкомфінпослуг, кредитним спілкам наприкінці першого кварталу 2017 р. фізичні особи були винні за споживчими кредитами 1 415,4 млн грн.

До речі, згідно зі статистикою Світового банку, 3 1 дол., виданого в кредит, банку повертають 0,03 дол., у цивілізованих країнах - 0,85 дол.

Причинами виникнення неплатоспроможності за кредитами споживчого характеру вважаються смерть або повна чи часткова непрацездатність позичальника. За настання іншої ситуації позичальник позбавляється можливості регулярно заробляти чи отриму- вати дохід. Тобто основним ризиком для домашнього бюджету боржника приймається його смерть, а додатковим - непрацездатність. До складу кумульованого ризику неплатоспроможності можна зарахувати ризик безробіття, що в більшості життєвих випадків може спричинити втрату доходу і неможливість повернути борг у встановлений термін. Окремим ризиком може виступати непередбачена втрата доходу або його нерегулярне отримання боржником [5].

Сьогодні споживчі кредити - це найбільш масові кредити. Вони переважно перераховуються в безготівковій формі. Відсотки, які повинен сплатити клієнт, на 2-4 пункти нижчі порівняно з нецільовими кредитами готівкою. Незважаючи на загальну тенденцію здешевлення кредитних програм, за словами банкірів, споживчі позики дешевшати не будуть. Зміни умов споживчого кредитування будуть стосуватися першого внеску (10-30\% вартості товару), терміну кредитування (більшість товарних кредитів видаються строком до року, максимально - до трьох років). Позики розраховані на прошарок населення з доходом від 100 дол. США [12].

Висновки. Споживче кредитування активно розвивається в нашій країні, що позитивно позначається як на добробуті домогосподарств, на результатах діяльності фінансово-кредитного сектору, так і на економіці України у цілому.

Рівень споживчого кредитування населення в Україні майже у шість разів нижчий від середньоєвропейського, тому фінансово-кредитний сектор повинен запропонувати населенню привабливі та різноманітні кредитні послуги.

Необхідно використати досвід кредитування закордоних банків для розширення кредитного ринку, щоб кредити стали доступнішими, зручнішими і вигіднішими для вітчизняних домогосподарств.

\section{Список літератури:}

1. Причини, за якими кредитування - це один із найбільших ризиків для банківської системи України. 2018. URL : https://www.money24.ua/ua/prichiny-po-kotorym-kreditovanie-eto-odin-iz-naibolshih-riskov-dlya-bankovskojsistemy-ukrainy (дата звернення: 08.09.2019).

2. Торубка Л.В. Споживче кредитування в Україні: сучасний стан і напрями розвитку. Вісник Університету банківської справи Наџіонального банку Украӥни. 2011. № 3(12).

3. Смолій Я.В. назвав пріоритети НБУ на наступний рік. 2018. URL : https://www.rbc.ua/ukr/news/smoliy-nazvalprioritety-nbu-sleduyushchiy-1542796761.html (дата звернення: 08.09.2019).

4. Волкова Н.І. Концептуальні підходи щодо вдосконалення кредитування споживчих потреб населення. Економіка і організація управління. 2016. № 4(24). С. 143-152.

5. На які потреби беруть кредити українці? 2017. URL : https://globalcredit.ua/uk/novosti/na-kakie-nuzhdy-berutkredity-ukraincy (дата звернення: 08.09.2019).

6. Закон України «Про споживче кредитування» № 1734-VIII від 15.11.2016. URL : https://zakon.rada.gov.ua/laws/ show/1734-19 (дата звернення: 08.09.2019).

7. Вітка Ю.В. Правове регулювання споживчого кредиту: стан та перспективи. Фінанси Украӥни. 2013. № 10. С. 75-86.

8. Кредит по карті поляка. 2018. URL : http://ostarbeiter.vn.ua/kredyt-kp.html (дата звернення: 10.09.2019).

9. Іпотечний ринок. 2016. URL : https://pidruchniki.com/72383/ekonomika/dodatki_ipotechniy_rinok (дата звернення: 10.09.2019).

10. Соціально-економічний розвиток України за січень-серпень 2018 р. : статистичний збірник. URL : https://ukrstat.org>publicat>kat_u>publ1_u (дата звернення: 10.09.2019). 
11. Національний банк України. Звіт про фінансову стабільність. 2019. № 3. URL : https://bank.gov.ua/doccatalog/ document?id=50604904 (дата звернення: 10.09.2019).

12. Закредитованість населення України: 2016 - 2017 pp. : аналітичний звіт. URL : https://nabu.ua/images/tinymce/ file/IFC_GfK_Over_ind_ukr\% 20\% 281\%29.pdf (дата звернення: 10.09.2019).

\section{References:}

1. Prychyny, za yakymy kredytuvannia - tse odyn z naibilshykh ryzykiv dlia bankivskoi systemy Ukrainy [Reasons why lending is one of the biggest risks for Ukraine's banking system] (2018) Available at: https://www.money24.ua/ua/prichinypo-kotorym-kreditovanie-eto-odin-iz-naibolshih-riskov-dlya-bankovskoj-sistemy-ukrainy (accessed: 08.09.2019).

2. Torubka L.V. (2011) Spozhyvche kredytuvannia v Ukraini: suchasnyi stan i napriamy rozvytku [Consumer lending in Ukraine: current state and directions of development]. Visnyk Universytetu bankivskoi spravy natsionalnoho banku Ukrainy (electronic journal), vol. 3 (12).

3. Smolii Ya.V. nazvav priorytety NBU na nastupnyi rik. [Smoly YV named the NBU priorities for next year.] (2018) URL: https://www.rbc.ua/ukr/ news/ smoliy-nazval-prioritety-nbu-sleduyushchiy-1542796761.html (Accessed: 08.09.2019)

4. Volkova N.I. (2016) Kontseptualni pidkhody shchodo vdoskonalennia kredytuvannia spozhyvchykh potreb naselennia. [Conceptual approaches to improving lending to consumer needs of the population.] // Ekonomika i orhanizatsiia upravlinnia. vol. 4(24). 2016. - pp. 143-152.

5. Na yaki potreby berut kredyty ukraintsi? [What loans do Ukrainians take?] (2017) URL: https://globalcredit.ua/uk/ novosti/na-kakie-nuzhdy-berut-kredity-ukraincy (Accessed: 08.09.2019)

6. Zakon Ukrainy «Pro spozhyvche kredytuvannia» [Law of Ukraine «On Consumer Lending»], № 1734-VIII, vid 15.11.2016, yakyi nabrav chynnosti z 10.06.2017 r. Available at: https://zakon.rada.gov.ua/laws/show/1734-19 (Accessed: 08.09.2019)

7. Vitka Yu.V. (2013) Pravove rehuliuvannia spozhyvchoho kredytu: stan ta perspektyvy. [Consumer Credit Legal Regulation: Status and Prospects.] // Finansy Ukrainy. vol. 10 - pp. 75-86.

8. Kredyt po karti poliaka. [Credit on a Pole Map.] (2018). Available at: http://ostarbeiter.vn.ua/kredyt-kp.html (Accessed: 10.09.2019)

9. Ipotechnyi rynok. [Mortgage market.] (2016) URL: https://pidruchniki.com/72383/ekonomika/dodatki_ipotechniy_ rinok (Accessed: 10.09.2019).

10. Sotsialno-ekonomichnyi rozvytok Ukrainy za sichen-serpen 2018 roku. Derzhavna sluzhba statystyky. [Socioeconomic development of Ukraine for January-August 2018. State Statistics Service. (2019) Statystychnyi zbirnyk. «Ukraina u tsyfrakh» Arkhiv 2018 rik. URL: https://ukrstat.org>publicat`kat_u>publ1_u (Accessed: 10.09.2019).

11. Natsionalnyi Bank Ukrainy. Zvit pro finansovu stabilnist \#3. [National Bank of Ukraine. Financial Stability Report \# 3.] (2019) Available at: https://bank.gov.ua/doccatalog/document?id= 50604904 (Accessed: 10.09.2019).

12. Zakredytovanist naselennia Ukrainy: 2016 - 2017 Analitychnyi zvit. [Ukrainian population credibility: 2016 - 2017 Analytical report.] (2018) Available at: https://nabu.ua/images/tinymce/file/IFC_GfK_Over_ind_ukr\% 20\%281\% 29.pdf (Accessed: 10.09.2019).

\section{ОСОБЕННОСТИ КРЕДИТОВАНИЯ НАСЕЛЕНИЯ В УКРАИНЕ}

В статье исследованы закономерности и особенности кредитования домохозяйств в Украине. Отмечено, что в современных условиях в Украине выросла и роль кредита в формировании финансовых ресурсов отечественных домохозяйств. Определены факторы, влияющие на объемы кредитов: сезонность, возраст заемщиков, пол заемшиков, принадлежность к сфере или области деятельности и др. Дано определение закредитованности населения. Под чрезмерно закредитоваными заемщиками предложено понимать и тех, кто задерживает платежи. Определены основные факторы закредитованности населения в Украине: состояние общеэкономического развития; показатели уровня жизни населения; личные факторы; финансовая грамотность и финансовая дисциилина населения; факторы развития сферы кредитных услуг; другие. Сделаны выводы о необходимости развития кредитования домохозяйств в Украине, потому что оно положительно сказывается на благосостоянии домохозяйств, на результатах деятельности финансово-кредитного сектора и на экономике Украины в целом.

Ключевые слова: кредитование домохозяйств, потребительские кредиты, ипотечные кредиты, заемщики, закредитованность населения, факторы закредитованности. 


\section{FEATURES OF POPULATION LOAN IN UKRAINE}

The article explores the patterns and characteristics of lending to households in Ukraine. It is noted that in modern conditions in Ukraine the role of credit in the formation of financial resources of domestic households has grown. The factors affecting the volume of loans are identified. Namely: seasonality, age of borrowers, gender of borrowers, other industry or field of activity. The experience of some European countries in lending to the population is briefly analyzed. The cited European statistics show that $90 \%$ of the able-bodied Polish population lives on credit, and on average each resident of Poland owes a little more than 800 euros to banks. It has been shown that in the Eurozone countries the cost of housing loans for the borrower is so low (3,5 - 3,75\%) that, compared to the inflation rate $(3,0-3,5 \%)$ for the consumer, the mortgage loan is virtually free. The definition of the debt load of the population is given. It is proposed to understand overly credited borrowers as those who delay payments. One of the signs of an increase in over-indebtedness of the population of Ukraine is that the share of borrowers who delayed payments on current loans by more than 30 days is higher than the share of those who had overdue payments on loans already repaid. Based on a study by GfK Ukraine, it is proposed to use two approaches to segmentation of borrowers that allow you to determine the depth of debt among the population, had experience in loans at a financial institution, and also to measure the likelihood of excessive debt. The level of loans is analyzed, it is paid late. The main factors of the debt load of the population in Ukraine, which are as follows: the state of general economic development; indicators of living standards; personal officials; financial literacy and financial discipline of the population; factors in the development of credit services; others. The main reasons are identified, it is an obstacle to the development of credit to the population. The main one is the deficit of solvent borrowers with officially confirmed incomes. Conclusions have been drawn on the need to develop lending to households in Ukraine, because it has a positive effect on the well-being of households, the results of the financial and credit sector, and the Ukrainian economy as a whole.

Key words: household lending, consumer loans, mortgages, borrowers, household lending, lending factors. 